\title{
Sheffield

\section{Generic Spaces in Middleton's The Triumphs of Truth (1613) and Michaelmas Term (1607)}

ANDERSON, Susan

Available from Sheffield Hallam University Research Archive (SHURA) at:

http://shura.shu.ac.uk/28370/

This document is the author deposited version. You are advised to consult the publisher's version if you wish to cite from it.

\section{Published version}

ANDERSON, Susan (2015). Generic Spaces in Middleton's The Triumphs of Truth (1613) and Michaelmas Term (1607). Cahiers Élisabéthains: A Biannual Journal of English Renaissance Studies, 88 (1), 35-47.

Copyright and re-use policy

See http://shura.shu.ac.uk/information.html 


\section{Generic Spaces in Middleton's The Triumphs of Truth (1613) and Michaelmas Term (1607)}

\section{Susan L. Anderson}

In John Frow's exploration of literary genre, he offers as "almost a definition" that genre consists of "a relationship between textual structures and the situations that occasion them" (emphasis original). ${ }^{1}$ The term 'situation' is, as Frow acknowledges, very broad. It is precisely its conflation of geographical position and historical circumstances that makes it a useful starting point for reading place and genre in different kinds of text. Over the following pages I shall explore the representation of particular places and spaces on different kinds of stages in London. The use of place in these theatrical representations, I shall argue, suggests that performance, taking place as it must do in time and space, inevitably involves what Julie Sanders calls "cognitive blending", whereby prior occupations of a performance space retain their potential to be brought to mind by spectators and participants during any current usage of the space. ${ }^{2}$ Through a comparison of The Triumphs of Truth (1613) and Michaelmas Term (printed 1607), I shall explore the representation of places in London where display was written into the kinds of space available, and determine some of the ways in which genres of performance and writing influence the way that space is defined. These examples will illuminate the relations between versions of London presented on theatrical stages and those presented in the streets of the city. These interrelationships give rise to the situations that occasion the textual structures under discussion.

My focus, then, is not only on playhouse drama, but also on the civic drama performed beyond the playhouse walls - the London Lord Mayors' shows, which combined dramatic performance, procession, and display on public streets. The shows' route was broadly the same every

\footnotetext{
${ }^{1}$ John Frow, Genre (London: Routledge, 2006), 13.

${ }^{2}$ Sanders uses this phrase in reference to the work of Mike Pearson on site-specific performance. Julie Sanders, The Cultural Geography of Early Modern Drama, 1620-1650 (Cambridge: Cambridge University Press, 2011), 122. This also applies to more conventional kinds of performance space - intertextual references in theatrical drama testify to the sense that previous plays and their performers and performances were still 'live' in the minds of the audiences. It is also clearly relevant to dramatic spectacle which makes particular play of space and location. See also Marvin Carlson, Places of Performance: The Semiotics of Theatre Architecture (Ithaca: Cornell University Press, 1989).
} 
year, though the stopping points for performances sometimes varied. They turned the streets into a theatre (and did so consistently each year by the end of the sixteenth century), ${ }^{3}$ and are thus a midpoint on a continuum between occasional, site-specific performance, and repeated use of a designated theatre. There is a mutually-influencing relationship between the city and its stages: locations in the city which functioned as site-specific stages in pageantry were also represented on theatrical stages in city comedies. Like civic pageantry, city comedy is a genre fundamentally concerned with London. Playwrights assumed a working familiarity on the part of their audience with locations in the city that are invoked on stage. Notwithstanding Sanders's warning against homogenising London, there is nevertheless a sense of proximity between the places envisioned on stage, and the theatres where these visions were conjured. This 'proximity' includes not just literal closeness, but also accessibility (in the broadest sense) and mental association. Here, there, near, and far are linguistic categories that speak of identity and power as much as they do of location. Their use as dead metaphors reveals how deeply spatiality is embedded in language and ideology. ${ }^{4}$ Furthermore, location in these London texts is dependent upon genre. Both civic pageantry and city comedy were written specifically for the venue in which they were performed, and those venues only hosted certain genres of performance. Thus, in these cases, place and genre are defined reciprocally. Furthermore, the subject matter of these two genres is also location, as they both represent and explore the nature of the city itself.

Building on Tim Fitzpatrick's discussion of how an illusory sense of 'elsewhere' is created offstage through onstage business and dialogue, I shall explore the ways in which 'elsewhere' is invoked in a non-theatrical space, before showing that in Michaelmas Term, 'elsewhere' is pathologically absent. I shall then show that place is relational in city comedies and civic shows, identifying how commercial and other kinds of exchange are structured by the spaces being depicted and the connectivity between them, concentrating on shop space in particular. Finally, I shall examine the languages of space used in the texts discussed, and the illusions of spatiality they create.

\footnotetext{
${ }^{3}$ See Tracey Hill's definitive account of the shows, Pageantry and Power (Manchester: Manchester University Press, 2010).

${ }^{4}$ See George Lakoff and Mark Johnson's classic account, Metaphors We Live By (Chicago: University of Chicago Press, 1980).
} 


\section{"Elsewhere" on and off stage}

Fitzpatrick's discussion of the "semiotic geography" of the early modern stage establishes how onstage dialogue and action not only create a sense of a wider fictional world of which the audience is only seeing a part, but also "articulate clearly and concretely for the audience how the unseen parts of that fictional world (the 'offstage') relate to the slice of it that we get to see onstage in any one scene". ${ }^{5}$ Fitzpatrick's sense of the mechanics of this interaction can be developed further, both because gesturing towards space 'elsewhere' is not confined to the kind of theatrical performance that he focuses on, and because the terms of this interaction are ideologically freighted. How these imagined places are presented as relating to each other is a politicisation of space and its meanings.

Middleton's Lord Mayors' shows portrayed the world on the streets of London. Locations, particularly nations, were regularly represented symbolically in tableaux, music, dance, speech and emblem. I have discussed elsewhere what that might mean in terms of the global "mental map" the shows create and promote, and the way that the configurations of power that this staging implies contributed to the foundations of imperial and colonial exploitation. ${ }^{6}$ Here, I wish to explore the opposite: how foreign locations might affect the mental map created of London, i.e. how 'elsewhere' might change 'here'. The fantastical mode of this pageantry presents a fantasy of control over space. The shows express the power of the merchant elite and their institutions, and their ability to define the city as a place embodied in and inhabited by them.

St Paul's is a particularly symbolically loaded location in pageantry. Central to what Lawrence Manley calls the "ceremonial heart" of the city, the cathedral and churchyard feature prominently in the Lord Mayors' shows as a stopping point for display and dramatic vignettes, as well

\footnotetext{
${ }^{5}$ Tim Fitzpatrick, Playwright, Space and Place in Early Modern Performance: Shakespeare and Company (Farnham: Ashgate, 2011), 22, 83.

${ }^{6}$ Susan Anderson, "Representations of India on Jacobean Popular Stages", Theatre Survey, 54.1 (January 2013), 7-25. The phrase "mental maps" is Joseph Roach's. See "The Global Parasol: Accessorising the Four Corners of the World", in The Global Eighteenth Century, ed. Felicity A. Nussbaum (Baltimore: Johns Hopkins University Press, 2003), 93-106 (106).
} 
as divine service. ${ }^{7}$ As a working church, St Paul's was a place of everyday ritual. Furthermore, as depicted in several city comedies, its environs were a key location for several kinds of commercial activities, and a place of everyday banter and barter. Michaelmas Term is a play of business and commerce, charting the misfortunes of Richard Easy who, having come to the city to finalise his inheritance, loses and then regains his patrimony through dodgy dealing and legal wrangling. In the play, St Paul's is a place where control of and access to space is negotiated. Act 1 scene 2 includes a reading of bills for chambers (that is, letting advertisements) that satirises estate agent-style rhetorical inflation whilst allowing for plenty of obscene punning (e.g., the chamber advertised has "a very provident back door" that is, apparently, "more convenient for a gentleman" (I.2.141-2). ${ }^{8}$ This humorous sequence is enabled by the audience's familiarity with the range of quotidian, liturgical, exceptional and spectacular kinds of performances that are possible in this version of St Paul's-a place that, in its theatricality, could be described as an 'offstage stage' itself.

The Triumphs of Truth was Middleton's first Lord Mayor's show, devised for the Grocers' Company. Celebrating his namesake, Thomas Myddelton, it was the most expensive show of the era. It included a dramatic device at St Paul's that emphasised the centrality of the cathedral by bringing an imagined marginalised place into it. Middleton's description is worth quoting at length, not least for its vivid attempt to locate the reader at the time and place of the performance:

[The pageants and procession] passing on till they come into Paul's Churchyard, where stand ready the five islands, those dumb glories that I spake of before upon the water: upon the heighth of these five islands sit five persons [...] No sooner can your eyes take leave of these, but they may suddenly espy a strange ship making toward, and that which may raise greater astonishment, it having neither sailor nor pilot, only upon a white silk streamer these two words set in letters of gold, Veritate gubernor: I am steered by Truth. The persons that are contained within this little vessel are only four: a king of the Moors,

\footnotetext{
${ }^{7}$ Lawrence Manley, Literature and Culture in Early Modern London (Cambridge: Cambridge University Press, 1995), 221-39.

${ }^{8}$ All references to texts by Middleton are taken from are taken from Thomas Middleton, The Collected Works, ed. by Gary Taylor and John Lavagnino (Oxford: Clarendon Press, 2007) and given as line numbers in the text.
} 
his queen, and two attendants of their own colour; the rest of their followers people the castle that stands in the middle island (389-407).

The king's account of the "strange gazes" of the "white people" (412) at seeing a "king so black" (415) has been identified by Gary Taylor as the first recorded usage of the term "white" as an identity category. The circumstances of this usage are based on the text's embeddedness in a culture that understood complexion as interlinked with place. Thus it instantiates a sense of 'here' in opposition to 'there', based on colour. ${ }^{9}$ The complexion of the ship's passengers (and, by implication, "their followers") denotes a faraway place. This visually demarcated sense of 'here' and 'there' violates the laws of physical space in its fantasy of the elsewhere being both present and far away. The ideology of control that this represents is made clear when the black characters turn and bow to "the temple of St Paul" (461). If St Paul's synechdocally stands for London, then this gesture literalises Sara Ahmed's assertion that "the Orient is made oriental as a submission to the authority of the Occident". ${ }^{10}$ An even clearer image of control over space is the depiction of Honour with his foot on the globe in The Triumphs of Honour and Virtue (1622). He declares:

\author{
I, Honour, overtopping all, \\ Here fix my foot on this orbicular ball, \\ Over the world expressing my command (292-4)
}

Honour's command sets him outside of the spatial realm, but simultaneously at the very "top" of a spatially-imagined hierarchy. This image intermingles global trade and its world-crossing with the riches it promises, and the social status and political power that they bring. ${ }^{11}$ It translates travel across space into a metaphorical climb to the top, and enables wealth to be repeatedly cast as virtuous

\footnotetext{
${ }^{9}$ Gary Taylor, Buying Whiteness: Race, Culture and Identity from Columbus to Hip Hop (New York: Palgrave Macmillan, 2005), 125.

${ }^{10}$ Sara Ahmed, Queer Phenomenology (Durham: Duke University Press, 2006), 114.

${ }^{11}$ Brenner shows that by the early seventeenth century, the government of the City of London had gone from being dominated by cloth traders focused on Northern European markets to global merchants trading a much wider range of goods. See Robert Brenner, Merchants and Revolution: Commercial Change, Political Conflict, and London's Overseas Traders, 1550-1653 (Cambridge: Cambridge University Press, 1993), 3-4.
} 
industry. If the merchants are London, then their profits are good for all. As representatives of their city, they (ad)venture into the rest of the world, where they accumulate the wealth that they bring back. ${ }^{12}$ The portrayal of 'elsewhere' in the shows establishes a proto-nationalism that homogenises the London audience to enable a sense that the economic advantages of the merchant elite accrue to all.

The sense of the absent elsewhere as the source of economic riches replicates the way that land operates as the ultimate object of desire in Michaelmas Term. Quomodo, a woollen draper, wishes to cozen Easy, a naïve country gentleman, of the land he has recently inherited. No scenes take place on this land; it can only be conjured for us as an imagined elsewhere. Even when Quomodo envisions himself actually being on Easy's estate, his anticipation of the pleasures that possession of the land will bring is expressed through absence. Quomodo imagines how jealous acquaintances back in London will speak of him when he is away:

Whither is the worshipful Master Quomodo and his fair bedfellow rid forth? - To his land in Essex! - Whence comes those goodly load of logs? - From his land in Essex! - Where grows this pleasant fruit, says one citizen's wife in the Row. - At Master Quomodo's orchard in Essex. - O, O does it so? I thank you for that good news, i'faith.

(III.4.15-19)

His absence is a signifier of his ill-gotten wealth. So too are the logs and fruit that are the produce of the land. These tradable commodities make the journey to London on his behalf, simultaneously constituting and representing his own value. Clearly the natural resources of the land tie this sense of status closely to the specificity of place because this is the kind of wealth that cannot be acquired directly in the city except through exchange. But Quomodo cannot imagine these commodities as useful objects in themselves. Rather, it is their exchange that functions as a kind of performance or reassurance of value that is supposedly inherent. Although the land that is the source of his produce could be a referent that lies behind the sign, Quomodo can only understand value in terms of the sign

\footnotetext{
${ }^{12}$ This portrayal directly refutes the concerns of contemporary economists and politicians that international trading companies were draining resources - specifically bullion - from the nation. See Brenner, Merchants and Revolution, 31-2.
} 
itself. His wealth needs interpreters to create its meaning. Most strikingly, once he possesses the deeds to the land, he moves immediately from imagining travelling there to thinking about what will happen in his ultimate absence, i.e. his death. Driven to find out whether his son will indeed squander his inheritance, he fakes his own death, avowing "I am as jealous of this land as of my wife to know what would become of it after my decease" (IV.1.120-1).

Represented metonymically in the play by the paper deeds that confer ownership, the land is commodified and fetishized, but never present. Its physical reality is only ever potential because despite the sense that land is an independent guarantor of meaning and value, meaning and value depend upon interpretation. The absence of this object of desire is, in fact, fundamental to its representation, and to the wider sense of place generated by the play. 'Elsewhere', constituted in the practical ways suggested by Fitzpatrick, becomes a Lacanian object of desire. The referent is permanently off-stage. Any actual location and characteristics become irrelevant. The 'value' inheres in the sign.

Quomodo's obsession with absence also reminds us that being in one place necessarily entails not being in another, ontologically speaking. Thus, thinking about place entails thinking about being and not being, as Quomodo's death fantasy so vividly demonstrates. But it also speaks to the possibilities and impossibilities of access and orientation, of where one is able to go from here. As Ahmed observes "[w]hat is reachable is determined precisely by orientations that we have already taken". ${ }^{13}$ Place, therefore, must be considered relationally, because levels of perceived connectivity are inseparable from it. Certainly, in the texts considered here, connections between places are paramount. Connectivity is the central mechanic of the Lord Mayors' shows, based as they are around a ceremonial procession. Many features of The Triumphs of Truth incorporate a sense of connection or movement between places: the processional form itself, the use of the river earlier in the day, the metaphors of journeys that recur in the speeches, and the repeated evocation of the medieval quest form are all ways in which the form and execution of the event engages with this theme.

The personification of Error within the show is in itself a spatial metaphor that portrays morality as pathfinding. The theme of straying from the singular way of truth is frequently invoked to

\footnotetext{
${ }^{13}$ Ahmed, Queer Phenomenology, 55.
} 
contrast the "many dangers ...| And ways most pleasant" of Error, with Truth who "has but one" (235-6). Error sneers at the "one foolish way" of Truth, and boasts that he "can run | Over a hundred with delight and pleasure, | Back-ways and by-ways, and fetch in my treasure" $(304,308-10)$. The show itself, of course, follows a single, designated route. This contrast between the multiplicity of sin and the singularity of virtue is suggestive of Christ's declaration in John 14:6 that he is the way, the truth and the life - a passage that echoes throughout the show. The enactment of the procession connects this well-known piece of scripture with the literal journey of the show through London, and the metaphorical future course of the mayoralty.

In Michaelmas Term, by contrast, movement among and between different places along multiple routes denotes power, control and knowledge. Indeed, the circulation of people, assets and cash (which might itself be described as liquidity) is the premise of the main plot. The central con hangs on the supposed stoppage of the passage of goods to Middleburgh. Complex systems of credit, grounded on the difference in value of the same commodity between different markets, are invoked to lure Easy into signing the bond that will forfeit him his estate.

The greater access a character has (or boasts of), the more power that character has, or can claim. In Michaelmas Term, access is associated with forms of credit. Easy's wide-eyed assertion that "Blastfield"'s credit seems "very spacious here i'th'city" (II.1.102) is immediately followed by Shortyard (who is disguised as "Blastfield") boasting that his gentlemanly demeanour gives him access to merchants' wives as well as their cash. This credit is generated by being in the right places, as Shortyard attests that he carries his "water all London over, | Only to deliver it proudly at the Standard" (II.1.109-10). This convergence of metaphors of credit, space, access/entrance, sexual intercourse and bodily excretion rehabilitates Error's sinful multiplicity and recasts it as witty mastery of the physical environment.

The figures of merit on pageant stages are often very close to those whose commercial and mercantile activities are satirised in city comedy. Middleton's shows avoid this bind by arguing for liberality. Despite the moral outrage of Error's unrestricted movements in The Triumphs of Truth, metaphors of circulation nevertheless create an ethics of wealth whereby the flow of bounty is a 
circuit whose completion guarantees the virtue of the wealthy elite. ${ }^{14}$ As Honour remarks at the end of the 1617 show, "Nothing deads Honour more than to behold | Plenty cooped up, and Bounty faint and cold" (272-3). Thus, honour is dependent upon a bipartite flow of virtuous largesse. The merchants' accrued profits are evidence of their virtuous industry, but for the maintenance of virtue they must be given away in liberality. The procession of the mayor and livery companies publicly symbolises their role in bringing wealth to the place they move through. Middleton's use of the title "triumphs" for all but one of his shows is a clear appeal to the early modern understanding of the Roman triumph and its association with the distribution of booty and, by extension, a prosperity grounded in elsewhere. ${ }^{15}$

\section{Exchange}

Although the Lord Mayors' shows ostensibly speak of charity and non-capitalist forms of exchange, they are in fact dedicated to celebrating accumulation. The arguments for magnificence and largesse that they present allow for personal wealth to be constructed as ethically acceptable within a culture in which several lucrative financial practices (such as usury and hoarding) were severely proscribed. ${ }^{16}$ The shows needed to link suspect social and economic practices with more familiar forms of exchange between different cultures and locations.

For instance, in The Triumphs of Truth, the king of the Moors speaks of a religious conversion engineered by trade. In his speech it is the abstract "truth" of the "English merchants, factors, travellers" (i.e. not the individuals themselves) that held "commerce" with the "spirits" of the Moors. This is a parallel process that happens just as "their affairs" held commerce "with us" (437-9). In other words, religious conversion happens effortlessly, on a higher spiritual plane, without the

\footnotetext{
${ }^{14}$ Ceri Sullivan explores the notion of flow more literally in relation to The Triumphs of Truth, A Chaste Maid in Cheapside and Middleton's entertainment for the opening of the New River in "Thomas Middleton's View of Public Utility", The Review of English Studies, 58 (2007), 162-74.

${ }^{15}$ See Anthony Miller, Roman Triumphs and Early Modern English Culture (Basingstoke: Palgrave, 2001). See also Mary Beard, The Roman Triumph (London: Harvard University Press, 2007), especially pp. 153-9.

${ }^{16}$ See Eric Kerridge, Usury, Interest and the Reformation (Aldershot: Ashgate, 2002).
} 
participants necessarily even being aware of it. This curious formulation recasts the problematically Catholic notion of missionary conversion through the metaphorical elasticity of commerce. Furthermore, it also works in reverse, sanctifying the negotiations of trade and mitigating any sense of unfair exchange. ${ }^{17}$ In a symbolic two-for-one deal, Middleton's imagery both ascribes evangelical power to the laity, and specifically makes this kind of spiritual virtue inextricably linked with the accessibility achieved through trade. The king of the Moors' journey extends these sanctifying implications, being presented as a kind of pilgrimage to find the "place, where these good spirits were bred" (444). This is, of course, London, again represented by St Paul's. Later in the show, the Lord Mayor himself is charged with repeating the pilgrimage to St Paul's on a weekly basis. Thus, mercantile journeys lead to wealth and spiritual enlightenment, both of which are located at London's cathedral church.

Works associated with Middleton explore economic exchange more literally in their repeated depiction of a place dedicated to such activity: the shop, a site which features in five of the twelve city comedies in the collected works of Middleton. ${ }^{18}$ As Leslie Thomson points out, the shop is a gendered space, where it is accepted and expected that women will interact with men, barter and make transactions. ${ }^{19}$ Middleton's plays are highly attuned to the ways that shops can simultaneously work with and against received notions of gender, class, wealth, and private/domestic and public spaces. Because of the inherent importance of commerce to this location, shop scenes concentrate the nascent capitalist dynamics of the city into a space where they can be tested on a human level.

In Michaelmas Term, Quomodo delights in the darkness of his shop, explicitly acknowledging it as a place of deception, and instructing his lackey Falselight to "make my coarse commodities look sleek" by placing them near the "trap-window" (I.2.86-8). Jokingly referring to the low levels of visibility in shops as "misty weather", Quomodo reveals that a shop is a space of illusion where the balance of knowledge can be manipulated through spatial configurations. But although Quomodo thinks that he has ultimate control of the space, other areas of occupation are unknown to him.

\footnotetext{
${ }^{17}$ Middleton figures conversion as trade even more explicitly in 1622's The Triumphs of Honour and Virtue.

18 These are The Patient Man and the Honest Whore (aka The Honest Whore Part 1), Michaelmas Term, A Trick to Catch the Old One, The Roaring Girl, and Anything for a Quiet Life.

${ }^{19}$ Leslie Thomson, “ 'As proper a woman as any in Cheap': Women in Shops on the Early Modern Stage”, Medieval and Renaissance Drama in England, 16 (2003), 145-161.
} 
Standing in the upper part of the shop enables his wife Thomasine to see what is going on without those below realising. The sympathy and desire she feels for Easy as a result ultimately leads to the undoing of Quomodo's schemes. He attempts to engineer the action in his shop, but fails to consider the ways that others are also using the space.

Thomasine's affective response to the gulling of Easy reflects exactly the axiomatic adulterousness of citizens' wives and initiates the turning of the tables on Quomodo. It also neatly reflects the relationship between the audience and the display on stage. Thomasine's superior view of proceedings parallels the audience's apparent ability to observe without being observed. More subtly, if the audience shares her sympathy for Easy, then the play's denouement, where Quomodo gets his comeuppance and Easy gets his land back, becomes much more satisfying. The shop therefore works as a model for the kinds of display and response that are being enacted and provoked on the theatrical stage. Furthermore, it expresses the commercialised culture of both spaces. If shops are like theatres, it also turns out that theatres are like shops. They are places where finished commodities can be supplied for a charge, even if what is being bought might have seemed to be non-commodifiable'things' such as experience, community, and emotion, for example.

This emphasis on retailing commodity is precisely in line with the kind of shop that was most likely to be found on the route of the Lord Mayors' shows. Cheapside, whose very name advertises its status as the most prominent shopping street in the city, ${ }^{20}$ is a place of display in several senses. Lawrence Manley has pointed out that it is precisely this commercial area that formed the core of ceremonial processions both civic and royal, ${ }^{21}$ and Derek Keene notes Cheapside as a clear example of how shops in the major thoroughfares of medieval and early modern cities tended to focus on retail rather than manufacture. He argues that this is no coincidence:

\footnotetext{
${ }^{20}$ The word cheap initially meant bargaining more generally (rather than a particularly low price necessarily). The $O E D$ lists Cheapside as an example of the way that the term comes to denote a market in place names.

${ }^{21}$ Manley, Literature and Culture, 221-39.
} 
fronting on to some of the most important spaces for public assembly in the city, the shop had a distinctive social role, both as the focus for special patterns of behaviour and as one of the most visible features of the landscape which expressed the city's identity. ${ }^{22}$

The overlaying of commercial and ceremonial spaces occurs because they both 'sell' a particular vision of the city. Although Garrett A. Sullivan is right that not everything about the city is ceremonial, the process of cognitive blending means that, in certain locations, even the quotidian is spectacularised. ${ }^{23}$ The shops on Cheapside displayed goods in a manner that was contiguous with the way that the city was represented in ceremonial display. ${ }^{24}$ The different kinds of display that operated on these streets formed a kind of palimpsest — performances could be 'read' simultaneously with other events and activities whose traces lingered. Habitual behaviours of one sort (shopping, travelling, and social interaction) are overlaid by others (annually repeated display and ceremony). ${ }^{25}$ The structuring of memory through the organisation of space interacts reciprocally with the ideological underpinnings of the shows.

In his discussion of social ritual, Paul Connerton emphasises the importance of habit, or the "accumulative practice of the same" ${ }^{26}$ I understand habit as the repetition of particular arbitrary decisions within a closed system of an apparent range of choices. Concrete elements of place (e.g. buildings and streets) therefore structure habit. Connerton refers to Halbwachs in order to argue that

it is to our social spaces - those which we occupy, which we frequently retrace with our steps, where we always have access, which at each moment we are capable of mentally

\footnotetext{
${ }^{22}$ Derek Keene, "Shops and Shopping in Medieval London", in Medieval Art, Architecture and Archaeology in London, ed. by Lindy Grant (Leeds: British Archaeological Association, 1990), 29-46 (29).

${ }^{23}$ Garrett A. Sullivan, The Drama of the Landscape: Land, Property, and Social Relations on the Early Modern Stage (Stanford: Stanford University Press, 1998), 201-2.

${ }^{24}$ This is particularly evident in the ways that this space was carefully regulated (i.e. the zoning of particular parts of the street so that only one kind of business can operate there). Sometimes these kinds of zones emerged organically, through similar kinds of businesses grouping together, often in 'rows', but at other times the city authorities deliberately regulated the space in order to promote or discourage particular behaviours. See Keene, "Shops and Shopping", 33.

${ }^{25}$ It must be recognised that the textual descriptions of the shows tend to direct our focus towards what is different about each year's show because they catalogue the speeches and figures that changed from year to year (though there is a good deal of repetition and recycling here, too).

${ }^{26}$ Paul Connerton, How Societies Remember (Cambridge: Cambridge University Press, 1989), 29, 34.
} 
reconstructing - that we must turn our attention, if our memories are to reappear. Our memories are located within the mental and material spaces of the group. ${ }^{27}$

The configuration of the city creates a certain set of possibilities, with time, place, and person coming together to form situation. As Andrew Gordon points out, people and place are both needed to create the city in these terms:

[The] pageants perform their version of London within the space of the city itself with the pageant floats carried through the city streets. The members of the Livery Companies and the civic officials circulate within the city of which they themselves are representatives, performing the constitution of which they are a part. The mayoral conception of the city thus preserves the conjunction of representative spaces and the social body which together constitute the notion of a city performed in ceremony. ${ }^{28}$

The shows repeatedly affirm a configuration of place and people that reinforces civic authority. Their representation of place contributes to a coercive shaping of the city's space in accordance with the political and ideological preferences of a particular sub-group of its citizens. The presentation of the same locations on theatrical stages confirms that the 'everyday' is a mode of performance that constructs place just as much as the 'exceptional', and that these two categories are not as different as they might seem. London's retail culture as envisioned by Middleton in his city comedies was a version of the spectacularised everyday, which emphasised the performative nature of habitual behaviours.

\section{The (inter)textuality of place}

\footnotetext{
${ }^{27}$ Connerton, How Societies Remember, p. 37.

${ }^{28}$ Andrew Gordon, "Performing London: The Map and the City in Ceremony", in Literature, Mapping and the Politics of Space in Early Modern Britain, ed. by Andrew Gordon and Bernhard Klein (Cambridge: Cambridge University Press, 2001), 69-88 (83).
} 
Joseph Roach has argued that London theatre of the late seventeenth century onwards offers a kind of "vicarious" experience of travel, bringing a vision of elsewhere into the theatre itself through fetishized tokens. ${ }^{29}$ In the examples discussed here, however, the audience does not vicariously experience a distant and inaccessible place, but the quotidian reality of the city that they inhabit. Recurring metaphors of space within these texts give clues to the ideological topography of the mental map of the city that they generate. For example, place and space are consistently described as equivalent to, or represented by, women's bodies. In terms of the city, this equates to a pleasurably accessible, but morally dangerous whorish body, whereas the country estate of the kind that Quomodo desires is figured as a more refined and socially elevated woman (unsurprising, considering the importance of land ownership in defining social status):

$\mathrm{O}$, that sweet, neat, comely, proper, delicate parcel of land, like a fine gentlewoman i'th'waist, not so great as pretty, pretty; the trees in summer whistling, the silver waters by the banks harmoniously gliding (II.3.90-4).

Land, its possession, and access are conceptualised in terms of male control over women and women's bodies, just as women's bodies are also often conceptualised as land (most notoriously by John Donne). In The Triumphs of Truth, London is personified as the mother of her citizens, and in several later shows, nations and other kinds of place are represented by female figures. The mental map of the city is thus consistently constituted in gendered terms across these genres, making different kinds of orientation possible for different kinds of bodies.

These textual traces of seventeenth-century performances can provide insight into contemporary place and space. Nevertheless, it behoves us to remember that, for literary critics, it is the traces themselves that, ultimately, are the object of enquiry, as Philip Schwyzer has pointed out. ${ }^{30}$ The introduction to The Triumphs of Truth establishes a kind of textuality of place through Middleton's self-consciously chauvinist claims about the superlative quality of London's civic

\footnotetext{
${ }^{29}$ Joseph Roach, "The Global Parasol”, 94.

${ }^{30}$ Philip Schwyzer, Archaeologies of English Renaissance Literature (Oxford: Oxford University Press, 2007), 18-19.
} 
ceremonial. This is based on the idea that an "inquisitive man" (49), having consulted the "chronicles, histories, [and] records" of such ceremonies (i.e. texts like Middleton's), would inevitably recognise London's superiority. Actually visiting these places and experiencing their festivities is not necessary, it seems. Just as it is in contemporary travel literature, place is not preserved in the text, but created. ${ }^{31}$ Such texts memorialise particular elements of space and erase others, and the way in which here is constructed in them establishes the terms upon which it will continue to develop.

The conclusion of The Triumphs of Truth vividly asserts its vision of time and place:

This proud seat of Error lying now only glowing in embers - being a figure or type of his lordship's justice on all wicked offenders in the time of his government - I now conclude, holding it a more learned discretion to cease of myself than to have Time cut me off rudely: and now let him strike at his pleasure. (788-93)

The performance, its aftermath, the tenure of the new lord mayor, the writing of the text and every subsequent reading of it are collapsed into a universalising present tense that creates the illusion of a presence in a space. It recalls a performance that itself created an illusion—or a particular vision—of place. For readers of these texts now, the gestures towards a no-longer-common common knowledge have the same effect as the gestures identified by Fitzpatrick on the theatrical stage, referring to an ever-absent elsewhere.

These texts generate a sense of the 'situation' of London that encompasses the physical environment, inhabitants and their behaviour, the past as memorialised through habit, and the associations created by these very texts themselves. Statements about place, and about relations between places, both demonstrate and shape the perceptions of inhabitants of those places, offering particular possibilities for understanding place and modes of acting and reacting within it. Those statements also offer readers long after the fact the opportunity to recognise the ways in which the

\footnotetext{
${ }^{31}$ See Jan Borm, "Defining Travel: On the Travel Book, Travel Writing and Terminology", in Glenn Hooper and Tim Youngs, eds, Perspectives on Travel Writing (Aldershot: Ashgate, 2004), 13-26.
} 
kinds of performance that are enacted in a place and about a place reveal that the physical experience of that place has a reciprocal relationship with its imaginative construction.

Leeds Trinity University 